\title{
PATH ANALYSIS ON THE PERSONAL AND SOCIAL DETERMINANTS OF WORK PERFORMANCE IN COMMUNITY HEALTH WORKERS IN SURAKARTA, CENTRAL JAVA
}

\author{
Restu Pangestuti'), Yulia Lanti Retno Dewi²), Endang Sutisna Sulaeman²) \\ ${ }^{1)}$ Masters Program in Public Health, Universitas Sebelas Maret \\ ${ }^{2)}$ Faculty of Medicine, Universitas Sebelas Maret
}

\begin{abstract}
Background: Work performance of health workers is a multidimensional construct that includes their experience in fulfilling work tasks and results from the relationship between health worker resource, expectation, and structural conditions that operate within health service. This study aimed to investigate the personal and social determinants of work performance in community health workers (CHWs).

Subjects and Method: A cross sectional study was carried at 25 integrated health posts (posyandu) in Surakarta, Central Java, from June to July 2019. A sample of 200 CHWs was selected randomly. The dependent variable was work performance. The independent variables were age, education, marital status, knowledge, working at home, tenure, training, and information. The data were collected by questionnaire and analyzed by path analysis.

Results: CHW performance was directly and positively affected by age $\geq 38$ years old $(\mathrm{b}=1.85 ; 95 \% \mathrm{CI}=0.88$ to $2.81 ; \mathrm{p}<0.001)$, good knowledge $(\mathrm{b}=2.89 ; 95 \% \mathrm{CI}=1.87$ to 3.92; $\mathrm{p}<0.001)$, married $(\mathrm{b}=1.75 ; 95 \% \mathrm{CI}=0.79$ to $2.71 ; \mathrm{p}<0.001)$, working at home $(\mathrm{b}=$ 1.08; $95 \% \mathrm{CI}=0.80$ to $2.08 ; \mathrm{p}=0.034)$, tenure $\geq 3$ years $(\mathrm{b}=1.43 ; 95 \% \mathrm{CI}=0.42$ to 2.45 ; $\mathrm{p}=0.005$ ). CHW performance was indirectly affected by education level, training, and information.

Conclusion: $\mathrm{CHW}$ performance is directly and positively affected by age $\geq 38$ years old, good knowledge, married, working at home, tenure $\geq 3$ years. CHW performance is indirectly affected by education level, training, and information.
\end{abstract}

Keywords: work performance, community health workers

\section{Correspondence:}

Restu Pangestuti. Masters Program in Public Health, Universitas Sebelas Maret. Jl. Ir. Sutami 36A, Surakarta 57126, Central Java, Indonesia. Email: restupanges@gmail.com. Mobile: +6285741405163. 